\title{
Effect of phytotoxic solutions on the respiration of mycorrhizal and non-mycorrhizal spruce roots (Picea abies L. Karst.)
}

\author{
F. Pellissier and L. Trosset
}

Biopedology Laboratory, Savoie University, BP 1104, 73011 Chambery Cedex, France

\section{Introduction}

In the northwestern Alps, the natural regeneration of subalpine spruce forest has become increasingly diffuse and even non-existent. This deficiency is explained by numerous factors, including the rigorous climate, predation of seeds and attack by fungi. Among these causes, the undergrowth vegetation may have a phytotoxic effect on the young plants. This interaction was demonstrated in the laboratory by measuring the respiration of excised spruce roots.

Using oxygen consumption as an indicator of metabolism, we followed changes in this parameter, when mycorrhizal and non-mycorrhizal roots were placed in the presence of a plant extract or humus solution.

\section{Materials and Methods}

\section{Plant extracts}

The plant material (Vaccinium myrtillus and Athyrium filix-femina) was harvested in the sub- alpine spruce forest (rather open stand, subject to forestry law, northern exposure at an altitude of between 1600 and $1800 \mathrm{~m}$ ). It was dried at room temperature and ground to a powder. The material was then extracted in water by stirring for $12 \mathrm{~h}$ in demineralized water $(1 \%$ concentration), filtered at $4^{\circ} \mathrm{C}$ and then sterilized through a $0.22 \mu \mathrm{m}$ membrane upon introduction into the measurement cell.

\section{Humus solutions}

The solutions were collected using a system of gutters after a period of rain (Dambrine, 1985). We chose 2 sampling stations: a mor humus under bilberry bushes and a mull humus under ferns. The solutions were sterilized as described above.

\section{The plants}

The non-mycorrhizal plants were obtained in vitro after disinfection of the seeds with hydrogen peroxide (Pellissier and Trosset, 1987).

The mycorrhizal plants were obtained by adding a mixture of the humuses obtained from the 2 stations to the vermiculite substratum. The plants were grown in a greenhouse for 16 mo. The mycorrhiza observed were Voiry (1981) type C12.

\section{Oxygen electrode (Hansatech Ltd.)}

This was used to follow the kinetics of oxygen consumption by excised roots in a liquid 
Table I. Kinetics of oxygen consumption by roots and mycorrhizas in the presence of various solutions.

\begin{tabular}{|c|c|c|c|c|c|}
\hline & \multirow{2}{*}{$\begin{array}{l}\text { Before } \\
\text { disturbance } \\
\left(\mathrm{nM} \mathrm{O}_{2} \cdot \mathrm{min}^{-1} \text {. }\right. \\
\left.10^{-4} \mathrm{~g}^{-1} \mathrm{DM}\right)\end{array}$} & \multicolumn{4}{|c|}{ After disturbance (\% initial $\mathrm{O}_{2}$ consumption) } \\
\hline & & $\begin{array}{l}\text { fern } \\
\text { fronds }\end{array}$ & $\begin{array}{l}\text { bilberry } \\
\text { leaves }\end{array}$ & $\begin{array}{l}\text { mull } \\
\text { solution }\end{array}$ & $\begin{array}{l}\text { mor } \\
\text { solution }\end{array}$ \\
\hline $\begin{array}{l}\text { Root } \\
\text { Mycorrhiza }\end{array}$ & $\begin{array}{r}530 \pm 132 \\
1490 \pm 559\end{array}$ & $\begin{array}{c}-29.2 \\
-4.6^{*}\end{array}$ & $\begin{array}{r}-34.9 \\
+41.2\end{array}$ & $\begin{array}{r}-51.2 \\
-5.6^{*}\end{array}$ & $\begin{array}{l}-47.8 \\
-37.7\end{array}$ \\
\hline
\end{tabular}

* Not significantly different from the consumption before disturbance at the limit $P=0.05$.

medium before and after injection of a solution (accurate to the nearest $\mathrm{nmol}$ ). The sample (mycorrhiza or excised root) was transferred into the measuring cell containing $1 \mathrm{ml}$ of demineralized water saturated with oxygen. After several minutes, the consumption rate of the sample became stable. This was the respiration before disturbance. We then injected $1 \mathrm{ml}$ of the test solution and followed the changes in the oxygen consumption to obtain the consumption after disturbance. Each test was repeated 10 times.

\section{Results}

The injection of each of the solutions into the measurement cell makes it possible to detect any interactions with the reaction medium $\left(\mathrm{H}_{2} \mathrm{O}\right)$. There was none in the present case.

The results are grouped together in Table I.

\section{Discussion - Conclusion}

The respiratory intensity of the mycorrhizal roots was higher than that of the nonmycorrhizal roots, with a particularly intense metabolic activity in the fungal partner of the symbiosis, as observed by Reid et al. (1983) for pine ectotrophic mycorrhi- zas. Moreover, the symbiosis leads to the 'birth' of a new entity with a greater metabolic activity and capacity for survival than the sum of those of each of the two partners (synergistic effect).

The non-mycorrhizal roots remained sensitive to the presence in their environment of each of the solutions (fern, bilberry, mull and mor). Persidsky et al. (1965) showed that it was difficult for young pines to grow on prairie soils when they were not infected by mycorrhizal fungi. Our experimental study in the laboratory, while passing from the macrocosm (ecosystem) to a mesocosm (controlled system) suggests the same conclusion: the survival of young plants depends upon their mycorrhization, since the respiratory activity of mycorrhizal roots was not disturbed when a fern extract or a mull solution (humus present under the ferns) was injected into the measurement cell.

However, the mycorrhizal state is not sufficient to counter the effects of phytotoxins. The qualitative aspect and, in particular, the fungal species involved in the symbiosis is of primordial importance. Hence the type of mycorrhiza used in our study (C12: probably involving species of the Russula genus) did not protect the respiratory activity of the plant roots against an injection of a bilberry extract or a solution of mor (humus present under the bilberry bushes). 
The next stage in these studies is the investigation of the microcosm (cell unit) to determine the part of the respiratory chain affected by the phytotoxins present in these solutions. Working on isolated mitochondria, like Moreland and Novitzky (1987), who showed that phenolic acids inhibited the electron transport chain, and by using various decoupling agents, such as FCCP (Merlin, 1988), it should be possible to obtain a better understanding of the interactions between phytotoxins and respiratory mechanisms at the cellular level.

\section{References}

Dambrine E. (1985) Contribution à l'étude de la répartition et du fonctionnement des sols de haute montagne. Massif des Aiguilles Rouges et du Mont-Blanc. Doctoral Thesis, Université Paris VII, France
Merlin G. (1988) Contamination par le P.C.P. d'écosystèmes aquatiques reconstitués dégradation et effets sur les végétaux. Doctoral Thesis, Univ. Grenoble I, France

Moreland D.E. \& Novitsky W.P. (1987) Effects of phenolic acids, coumarins and flavonoids on isolated chloroplasts and mitochondria. In: Allelochemicals: Role in Agriculture and Forestry. (Waller G.R., ed.), Am. Chem. Soc. Washington D.C. 23, pp. 247-261

Pellissier F. \& Trosset L. (1987) Effets du pH et de solutions humiques sur la respiration de racines d'épicéa mycorhizées ou non. $112^{\circ}$ Congrès national des Sociétés Savantes, Lyon 1987. Sciences III, 91-102

Persidsky D.J., Loewenstein H. \& Wild S.A. (1965) Effects of extracts of prairie soils and prairie grass on the respiration of ectotrophic mycorrhizae. Agron. J. 57, 311-312

Reid C.P.P., Kidd F.A. \& Ekwebelam S.A. (1983) Nitrogen nutrition, photosynthesis and carbon allocation in ectomycorrhizal pine. Plant Soil 71, 415-432

Voiry $H$. (1981) Classifications morphologiques des ectomycorhizes du chêne et du hêtre dans le nord-est de la France. Eur. J. For. Pathol. 11, 284-299 